\title{
Ruling Climate: The Theory and Practice of Environmental Governmentality, 1500- 1800
}

\author{
John Emrys Morgan* \\ Department of History, University of Warwick, Coventry UK \\ *Correspondence: john.morgan@warwick.ac.uk
}

\begin{abstract}
This one-day conference brought together scholars from across Europe and North America to discuss the relationship between governments and the environment in the early modern period. Papers discussed competing conceptions of environmental and climatic models and their use as instruments of control to justify a variety of social and economic interventions. With early career, established and leading scholars discussing environmental governmentality in global contexts, from the sixteenth to the eighteenth centuries, the breadth of research at 'Ruling Climate' was testament to the vitality of the environmental humanities, and its current status as a leading movement in contemporary historical research.
\end{abstract}

Keywords:

climate; environment; early modern; governmentality; determinism

Funding: [See page 136]

Peer review: This article has been subject to a double blind peer review process

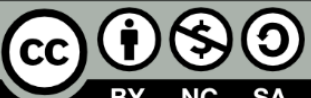

BY NC SA

(C) Copyright: The Authors. This article is issued under the terms of the Creative Commons Attribution NonCommercial Share Alike License, which permits use and redistribution of the work provided that the original author and source are credited, the work is not used for commercial purposes and that any derivative works are made available under the same license terms.
Global warming, ozone depletion and water, energy and food security are among the principal concerns of modern governments. Legislators vacillate between positions pushed by climate-sceptic industrial lobbyists on the one hand, and the massed ranks of research scientists on the other. Collectively, they appear insufficiently willing to make the drastic changes required to reverse the most negative impacts of anthropogenic climate change. But it has not always been this way. Five hundred years ago, the mutual influences of humanity and the climate were accepted and the relationship boldly utilised by governments across the world to improve the environments and populations over which they governed. On 16 May 2015, nearly forty scholars from across Europe and North America came together at the University of Warwick to discuss how these influences were understood, debated and deployed under a very different 'ruling climate'.

Much like today, the environment was integral to scientific inquiry and public policy in the early modern period. Spurred by the foundations of scientific societies, the rise of international correspondence networks and 
encounters with the 'foreign climes' of European colonies, natural philosophers began to ask how might the environment be used as a tool with which to improve economic productivity, financial power and human health and happiness. Governments deployed these ideas in schemes that drastically altered the physical environment. Large public and semi-public schemes sought to manipulate the physical world for economic and social benefit. Schemes such as the drainage projects of England and France were designed to rid the landscape of marshes and swamps, which produced air that was said to be 'cloudy, gross, and full of rotten harrs' and engender 'a rude, and almost barbarous, sort of lazy and beggarly people' (Dugdale, 1662: sig. A2v, 177). The climate was seen as a key influence on the character and organisation of a society. With the appropriate technological interventions, it could be turned into a valuable mechanism of social and economic change. These ideas, and the schemes in which they were manifested at a governmental level, had their foundations in Classical conceptions of the constitution of the human body and the physical world. These ancient 'climate theories', found in the works of Hippocrates, Plato, Aristotle and Ptolemy, were read, circulated and discussed throughout the renaissance and early modern periods, retaining a cultural and intellectual importance that imbued them with strong explanatory powers. The interpretation of these ancient texts thus played a large part in practices of landscape management, social policy, public health and medicine, and provided a lens through which Europeans looked at foreign climates and people.

Yet these ancient texts were not restrictive, nor did they represent an unchallenged and directly applicable set of concepts that early modern governors could use. The period between 1500 and 1800 witnessed the blossoming of natural philosophy, the spread of new agricultural and engineering technologies, and the concomitant retheorisation of nature, climate and meteorology. Just as intellectual and technological parameters shifted, so did physical ones. Humans dammed, drained, deforested and exchanged at greater rates than they had ever done before, all whilst global temperatures cooled in a period historians have termed the 'Little Ice Age' (Hughes, 2009: 149).

The period also witnessed nascent moves to sustain and conserve unique and particularly productive environments (Grove, 1995). 'Ruling Climate' then, sought to understand the relationship between these phenomena: how were classical theories of climatic influence received and adjusted to new contexts in the early modern period? What was the relationship between theories of climatic influence and the development of strategies to cope with and modify climate and the environment? How did early modern governors seek to both govern climate and govern their people through manipulating climate? The focus on governmentality brought 
together scholars working on governmental attempts to alter climates for human advantage, and to use climates to alter human behaviour. These operated on scales ranging from the individual and the microclimate, to the population and the global climate.

There is much to be gained from studying climate governance from a longterm perspective. Historians have recently made high-profile arguments about the value of thinking about the environment in the long term (Guldi and Armitage, 2015). This is in the face of recent work that has considered climate governance to be a recent phenomenon-a 2009 monograph on governing climate change began its historical introduction in 1988, for example (Bulkeley and Newell, 2009: 17). Delegates assembled at 'Ruling Climate' to discuss how we might conceive of an early modern environmental governmentality with attention to a much longer historical relationship between climates and techniques of control.

In his keynote address on the origins of climatology, Franz Mauelshagen (KWI Essen/Rachel Carson Centre, LMU Munich) presented a conceptual history of the idea of climate. Spanning a broad spectrum of literature, from the so-called foundational texts of climatology like Aristotle's Meteorologica (350 BCE), to more recent work by climatologists such as H.H. Lamb's Climate, History and the Modern World (1988), Mauelshagen argued for a disassociation of climate and weather before the nineteenth century. When we project a meteorological notion of climate back into the past, Mauelshagen argued, we construct a long, but fundamentally mistaken history of climatology. Instead, climate existed as something quite distinct from average statistical atmospheric measurements. In its ancient and early modern forms it was a geographical category that related to the location of a place, retaining a meaning much closer to its Greek original 'slope' or 'inclination'. The association of this location and place-focused study with barometric and temperature measurements came in the eighteenth century, as Europeans attempted to account for variability within supposedly uniform latitudinal zones. By reintegrating physical geography back into the history of climatology, Mauelshagen showed how this history of climatology was not just a history of Baconian measurement and weather observations. Such a link demonstrates how the intellectual history of science can lead us to new interdisciplinary collaborations in the future.

The first panel session on 'Thinking Environmental Influence in the Early Modern Period' continued with intellectual and cultural historical approaches to climate. Richard Spavin (Queen's University Belfast) offered a literary examination of the role of climate in the political writing of sixteenth-century French political philosopher Jean Bodin. Bodin is often cited as a climatic determinist (see for example Hodgen, 1971: 278; 
Sluyter, 2002: 224; Boia, 2005: 34), particularly because of his division of the climates of the world into the Classical categories of torrid, frigid and temperate, which were each home to populations that are industrious but unwise, wise but unindustrious and both industrious and wise respectively. Drawn in thirty-degree bands stretching north from the equator, Bodin thus located France as firmly temperate, with its people suitably industrious and wise. This theory of climate stipulated that France, as a temperate nation, should foster good governance, yet the experience of the Wars of Religion had shown this not to be the case. This, Spavin argued, shows Bodin's playful and ironic use of the climate as a rhetorical tool. In showing France to be a potentially ideal but malfunctioning state, Bodin used climate as a discourse with which to legitimise political criticism of its rulers.

Sundar Henny (University of Basel) picked up on a similar theme of reassessing environmental determinism in his paper on climate in Isaak Iselin's History of Mankind (1764). Henny demonstrated how Iselin used a developmental model of the evolution of human society to counter Montesquieu's deterministic view of the relationship between climate and societies. In the first of his eight volumes on the history of mankind, Iselin described the development of the individual, who was dominated by different qualities and inclinations at different developmental stages. In subsequent volumes he applied this schema to the development of human societies, furnishing his argument with examples from classical authors and travel accounts. In particular, Iselin used the work of Greek geographer Strabo to refute any causal link between 'genius' and geography. This systematic exploration of the history of mankind as shaped by itself, rather than climatic phenomena, provided a strong counterpoint to Montesquieu. Iselin's narrative of progress, Henny argued, demanded that environmental determinism be rejected, to show the possibility of human progress, to reject the consignation of vast areas of the world to perpetual underdevelopment and to buttress the project of universal history.

Moving from the study of texts to contexts, Michael Hill (Georgetown University) offered a third perspective on the intellectual history of climates. In 1643, the English Parliament sequestered books belonging to their political and military opponents in the civil war, particularly those of the London-based Royalist gentry and professional classes. Using the sometimes vague lists of books drawn up by the Committee for Sequestration, Hill pieced together the libraries of Parliament's political opponents. Using this circumscribed corpus of texts, Hill was able to reconstruct the intellectual worlds of the mid-seventeenth century English nobility. In these libraries, Hill showed that in and between these texts, understandings of domestic agriculture and tropical climates were 
interlinked, providing an important colonial intellectual context for the agricultural improvement projects of the mid-seventeenth century. Several important ideas predominated in these texts: that cultivability was inextricably linked to habitability; that where land could be improved, it should be improved; that place was defined by habitability (and vice versa); and that agricultural improvement was a tool with which to render the uninhabitable, habitable. By looking at agricultural and environmental texts in concert, Hill showed a tangible set of concepts that the landowning classes worked with in early modern England, providing depth and texture to current understandings of 'improvement' and environmental management.

William Cavert (University of St. Thomas, Minnesota) explored the intellectual history of early modern climatic phenomena from a fourth angle. In his paper on 'Winter and Discontent in Early Modern England', Cavert provided a rereading of early modern English attitudes towards extreme cold. Using diplomatic and domestic correspondence, Cavert was able to show how ideas about early modern climatic phenomena were deployed in reportage and explanation. He challenged Geoffrey Parker's influential recent conclusions that extreme weather events, particularly extreme cold and bad harvests, precipitated political unrest, leading to rebellion and state breakdown (Parker, 2013). Instead, Cavert showed how, in the English context, extreme cold did not engender particular 'discontent' in the seventeenth century. As snow fell and the Thames froze, international correspondence networks chattered not with rumblings of political dissent, but with stories of merriment, ice fairs and skating. The discontent that did emerge remained private, resulting from heat and nutrition deprivation, and never grew to levels that instigated social unrest. The crises that did ensue were slow and creeping, necessitating gradual and incremental governmental responses, rather than wholesale restructurings of the status quo.

In the spirit of Mauelshagen's keynote lecture, these papers questioned what we read, construct and understand as 'climate' in the past. They showed that understanding the history of how we think about climate is crucial to understanding the influence climate had on humans, and the impact humans had on climate in return.

These issues of the perceived influence of climate on people and their responses to those perceptions were picked up by Rebecca Earle (University of Warwick) in a second keynote lecture. Earle spoke on climate, travel and colonialism in the early modern world, with particular reference to the Spanish Americas. This was a period in which travel was considered dangerous and unwise. This was not because of any particular dangers in specific places, but rather due to the damage that would be 
done by being away from one's native country, soil and diet. Drawing on ancient humoral theory, early modern authors advised their readers not to change their diet too quickly lest their body should be thrown into a state of disequilibrium. Changes in diet should be phased in, so as to acclimatise oneself to new crops and cuisines. Even changes in the way one dressed could affect people's health. All of these changes were compounded when abroad because of the melancholia brought about by being detached from one's home. These ideas, Earle argued, provided significant obstacles for would-be travellers in an age of unprecedented travel and colonial expansion. However, Europeans countered these potentially fatal problems through diet. The maintenance of a European diet was seen as an essential part of surviving any trip abroad. Spanish American colonists went to extreme lengths to reproduce Iberian diets in their colonies. Royal orders stated that colonies had to be able to sustain European agriculture, and the treasure fleets that sailed the south Atlantic to Europe sailed back to the Americas laden with the most quotidian European foodstuffs: olive oil, red wine and wheat. Extreme care was taken over not only what settlers ate and drank, but what enslaved people were fed as well. Diet was seen as universally influential on human health. When slaves fell ill, they were provided with foods from the countries where they had been taken, such as yams. The Spanish crown even forbade the transportation of Amerindian people back to Europe as the influence of European diets and climates was deemed to be overwhelming, and would damage their supposedly delicate constitutions. Earle's paper showed how conceptions of material circumstance, diet and environment and the social practices of colonial society were all mediated through attitudes towards the body. Society and the environment are here inextricably linked in their influence on the human body, as governments and individuals sought to mitigate the impact of foreign customs and climates with the practical application of a humoral and climatic theory.

The papers in the second panel session brought out this theme of the relationship between environmental influence and human agency in a variety of managerial contexts. Three papers discussed changing attitudes to water resources, both static and flowing. Raphaël Morera (Centre National de la Recherche Scientifique/Centre de Recherches Historiques de l'Ouest) debuted recent research on the governmental management of French marshland in the seventeenth century. He showed how during the ancien régime the French monarchy created a new legal order devoted to the environment. This included new statutes devoted to the regulation of forests, marshes and rivers. The driving force behind these laws of the later sixteenth and seventeenth century was their potential to grow the French economy and expand its natural wealth. This environmental focus in early modern law, Morera argued, remains unaccounted for in current 
historiography. Jean Bodin credited the wealth of a country to the size of its population (Bodin, 1606), and in the twentieth century Michel Foucault argued that government was focused on the control and policing of people specifically (Foucault, 1978: 140). Morera linked the desire to control climates and the desire to control people through ancient humoral theory and early modern climate theory. Both Bodin and Montesquieu regarded swamps as signals of a lack of civilisation. They were seen as uncultivated, unmanaged and thus ungovernable zones over which the state had little power. They were the vestiges of a poorly organised state and the mark of bad political leadership. Thus, the French monarchy engaged in drainage enterprises with renewed vigour in the early modern period. Draining swamps and marshes served to integrate the exceptional climates of isolated, ungovernable wet zones within the 'true' French climate, at the same time bringing them under the purview of the state. These newly governable zones would be newly profitable zones, as more intensive forms of agriculture would provide more work for the poor and, according to a declaration in 1639, would enrich the Royal exchequer more than an entire Indian empire (Morera, 2005: 55).

Continuing the discussions about the improvement and management of water resources, Leona Skelton (University of Bristol) spoke on efforts to manipulate the flow, function and form of the River Tyne. Taking historiographical cues from Keith Thomas' Religion and the Decline of Magic (1971), Skelton argued that across the early modern period a greater desacralisation of nature and a disenchantment of the previously supernaturally imbued physical world created space for practical, protoscientific approaches to environmental management. These approaches were guided by desires to maintain the Tyne as an important trade link for Newcastle and North East England, and out of a nascent sense of environmental conservationism aimed at protecting the natural processes of the river. To meet these commercial and environmental goals, the Tyne's guardians - the Newcastle Corporation - used a variety of legal and technological means to reduce and redress human impact on the river. Regulations included ordering the removal of wharfs used in salt making, prohibiting ballast dumping by trade ships and forbidding building on intertidal mud flats. Together these orders were unable to satisfy all of Newcastle's commercial interests at the same time-the demands salt makers made of the river were incompatible with those made by commercial shipping, for example. Skelton showed how the Newcastle Corporation technologically and legally intervened in its local environment in the early modern period by using the concept of protecting natural processes (particularly the river's natural flow) to manage competing commercial interests, maintain Newcastle's economic position and, ultimately, to conserve the River Tyne. 
The final paper of the day drew on several themes that emerged throughout the conference: the influence of humoral medical theory on land management, the relationship between landscape and climate and a belief in the efficacy of large-scale structural engineering works to counter environmental problems. Anthony Carlson (School of Advanced Military Studies) spoke about the relationship between epidemic disease, wetland environments and the United States' 'climate crisis' of the 1790s. The Yellow Fever epidemics that ravaged the United States in the 1790s seemingly showed Americans that European methods of land management could solve the problems of North American environments. Yellow Fever was believed to infect humans through miasmas-bad airs that rose from standing and stagnant waters. In 1780 about twelve percent of the United States was covered in wetlands, leading to the belief that before Europeans had arrived, North America had suffered a great deluge of Biblical proportions. With so much arid land on the Western continent, most of the remaining wetlands were concentrated in the East where Europeans had colonised. Specifically, these wetlands, and the animal and vegetable matter that decomposed within them, were said to deprive the surrounding climate of oxygen, precipitating their unhealthfulness. Human interventions were also to blame-artificial inundations to create mill ponds contributed to the volume of standing water on the land, adding to the 'climate crisis'. The response to these problems was to drain vast areas of wetlands, and Carlson showed that by 1805, Yellow Fever ceased to be endemic in the United States. What the case study revealed was that, contrary to recent historiographical interventions, Americans could not just ignore their climate in the nineteenth century (Wood, 2010: 28).

The authors of The History Manifesto argue that a longue durée approach to historical environmental issues can illuminate alternative, more sustainable modes of production and 'give scientists and policy-makers on the ground a sense of where to look for possible futures' (Guldi and Armstrong, 2015). The presentations at 'Ruling Climate' reiterated this point. But they also showed how we do not just find solutions to current problems in the early modern past. Here we find some of their roots as well. The papers discussed deliberate anthropogenic climate change, the wilful political misrepresentation of climatic phenomena and the environmental foundations of the racialisation of difference, and showed that the early modern period and the present day are more similar than we might think. In early modern thought and practice, we can see some hints towards our current environmental crisis, yet all couched in a firm belief that humanity can change its environment. Together, what these papers can offer as a 'possible future' is the notion that with enough 
political will, climatic phenomena can be 'corrected' to sustain a diversity of life on Earth.

\section{Acknowledgements}

The conference organisers, John Morgan and Sara Miglietti (both at the University of Warwick) would like to acknowledge the kind help and assistance of Sue Dibben of the Humanities Research Centre (University of Warwick), and the financial support of the HRC, the Centre for the Study of the Renaissance, the Research Students Skills Programme, and the British Society for the History of Science. An archive of tweets and photos from the day is available as a Storify at http://storify.com/rulingclimate/rulingclimate.

\section{References}

Bodin, J. (1606), The Six Bookes of a Commonweale, trans. R. Knolles, London: G. Bishop

Boia, L. (2005), The Weather in the Imagination, London: Reaktion Books

Bulkeley, H. and Newell, P. (2010), Governing Climate Change, Abingdon: Routledge

Dugdale, W. (1662), The History of Imbanking and Drayning, London: Alice Warren

Foucault, M. (1978), The History of Sexuality, volume 1, trans. R. Hurley, New York: Random House

Guldi, J. and Armitage, D. (2015), The History Manifesto, Cambridge: Cambridge University Press

Grove, R. (1995), Green Imperialism: Colonial Expansion, Tropical Island Edens and the Origins of Environmentalism, 1600-1860, Cambridge: Cambridge University Press

Hodgen, M. T. (1971), Early Anthropology in the Sixteenth and Seventeenth Centuries, Philadelphia: University of Pennsylvania Press

Hughes, J. D. (2009), An Environmental History of the World: Humankind's Changing Role in the Community of Life, Abingdon: Routledge

Morera, R. (2005), 'La Politique Hydraulique des Rois de France au XVII Siècle. Des Constructions d'Emblèmes', Hypothèses, 2004, 49-60 
Parker, G. (2013), Global Crisis: War, Climate Change and Catastrophe in the Seventeenth Century, New Haven: Yale University Press

Sluyter, A. (2002), Colonialism and Landscape: Postcolonial Theory and Applications, Oxford: Rowman and Littlefield

Thomas, K. (1971), Religion and the Decline of Magic: Studies in Popular Beliefs in Sixteenth and Seventeenth Century England, Oxford: Oxford University Press

Wood, G. (2010), 'Environmental Hazards, Eighteenth Century Style', in Sadosky, L. J., Nicolaisen, P., Onuf, P. S. and O'Shaughnessy, A. J. (eds), Old World, New World: America and Europe in the Age of Jefferson, Charlottesville: University of Virginia Press, 15-31

\section{To cite this article:}

Morgan, John Emrys (2015). Ruling Climate: The Theory and Practice of Environmental Governmentality, 1500-1800. Exchanges: The Warwick Research Journal, 2(1), 128-137. Retrieved from:

http://exchanges.warwick.ac.uk/index.php/exchanges/article/view/70 